\title{
HISTOID RELAPSE IN LEPROMATOUS LEPROSY
}

\author{
Dear Editor.
}

W e would like to report a rare variety of lepromatous leprosy called 'Histoid leprosy' which has become uncommon in the era of multidrug therapy. Wade [1] in 1963 first time described skin lesions of lepromatous leprosy resembling a tumour which histopathologically showed well circumscribed tumorous collection of spindle shaped histiocytes in deep dermis and abundance of acid fast bacilli. The lesions are classically firm and succulent cutaneous nodules on apparently normal skin. This may appear de novo [2] or as a relapse case of lepromatous leprosy [3].

The present case was a 55-year-old ex-serviceman who was diagnosed as lepromatous leprosy in 1971. Old documents revealed that he had bilaterally symmetrical multiple hypopigmented lesions all over body with infiltration over face and ear lobules and glove and stocking type of sensory loss. All peripheral nerves were thickened but nontender. Bacterial Index was $6+$. He was treated with dapsone mono-therapy and became bacteriologically negative after 5 years with regression of lesions and nerve thickening. In October 96 he came for review with complaints of spontaneous appearance of nodular lesions on back and extremities of 2 months duration. No abnormality was detected on general and systemic examination.

Dermatological examination revealed multiple, painless, smooth, shiny, succulent nodules of 0.5 to $2 \mathrm{~cm}$ size on lower back, both arms and thighs. There was no infiltration of face or fresh hypopigmented lesion and no peripheral nerve thickening. During hospitalisation he also developed herpes zoster. Routine haematological investigation, urinalysis, LFT and blood sugar were normal. Slit skin smear showed AFB (L) from nodules. ELISA for HIV - 1/2 were non-reactor. The $\mathrm{CD}_{4}+\mathrm{T}$ cell count was $655 / \mathrm{cmm}$ and absolute lymphocyte count was $1140 / \mathrm{cmm}$. Skin biopsy from nodule showed collection of band of spindle shaped cells alongwith foamy macrophages and acid fast bacilli (Fig 1). Patient was put on WHO recommended multidrug therapy for multibacillary leprosy. He responded well to therapy and lesions regressed satisfactorily in next one year.

Before the introduction of multidrug therapy by WHO in 1982 [4] the relapse rate of multibacillary leprosy was reported to be as high as 19 per cent. This was mostly due to dapsone resistance [5]. The relapse rate has now come down to as low as 0.74 per cent in multi-bacillary cases following use of multidrug therapy [6]. The cause of relapse of leprosy after almost 20 years of bacterial negativity in our case is not clear. However, generalised immune depression due to old age as seen by low $\mathrm{CD}_{4}+\mathrm{T}$ cell count and low absolute lymphocyte count might have resulted in reactivation of leprosy as

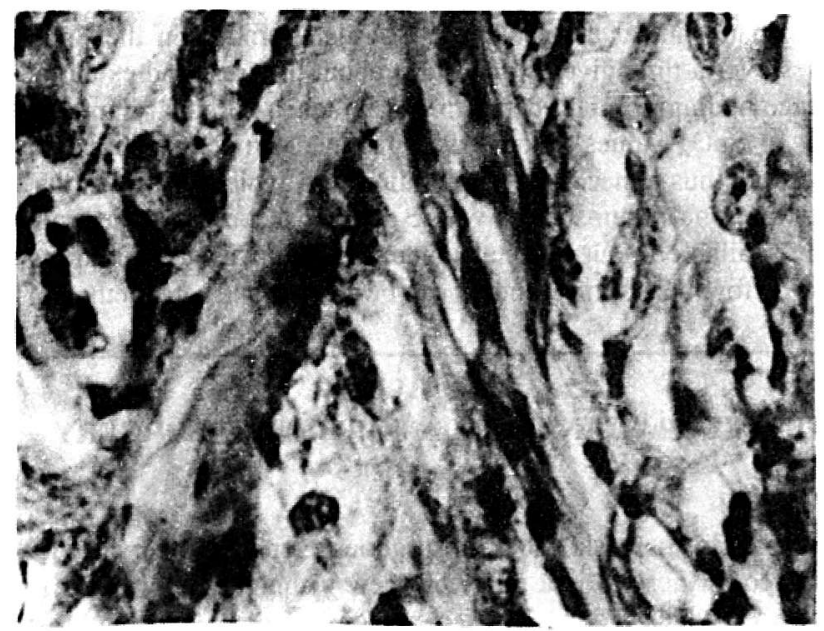

Fig. 1: a) Multiple spindle shaped cells in dermis $\times 10$.

b) Multiple spindle shaped cells with foamy appearance in dermis $x$ 40 .

well as herpes zoster. The aim of reporting this case is mainly to highlight the importance of regular check up of leprosy patients so that such cases could be identified early and treated adequately with multidrug therapy.

Lt Col CM GUPTA ${ }^{*}$, Col SK SAYAL ${ }^{*}$, Wg Cdr AK MALIK Lt Col ND ROY ${ }^{+}$

*Department of Dermatology \& Venereology, Armed Forces Medical College, and Command Hospital (SC), ${ }^{+}$Command Path Lab, Pune 411040.

\section{REFERENCES}

I. Wade HW. The histoid variety of lepromatous leprosy Internet J Lepr $1963 ; 31.129-42$.

2. Bhutani LK, Bedi TR, Malhotra VK et al. Histoid leprosy in North India Internet J Lepr 1974: 422: 174-81

3. Rodrigues JN. The histoid leproma: ts characteristic and significance. Internet J Lepr 1969; 37: 1-21.

4. Desikan KV, lyer CGS. Histoid variety of lepromatous leprosy. A histopathological study. Internet J Lepr, 1972: 40; 149-56.

5. WIIO study group on chemotherapy of leprosy for control programmes, Geneva, WHO 1982 Tech Rep series 676

6. WHO study group on chemotherapy of leprosy. Geneva, WHO 1994 Tech Rep series 847.

\section{PLETHYSMOGRAPHIC USE OF PULSE OXIMETER}

Dear Editor.

$\mathbf{P}$ lethysmographic capabilities of pulse oximeter can be utilised to assess efficiency of peripheral microcirculation apart from its main use $[1,2]$. We were able to assess adequacy of peripheral circulation after arterial injury at elbow following a supracondylar fracture of humerus in a 5 year old child. Brachial/radial artery injury is not uncommon following supracondylar fracture, which if re- mained unnoticed can result in a loss of limb. Palpatory method to assess adequacy of distal circulation has its own limitations and total reliance on it can prove to be disastrous. In this child we were unable to feel radial/ulnar pulse at wrist, therefore we utilised finger probe of pulse oximeter to assess adequacy of circulation in distal hand and compared it with healthy left hand. We noted significant difference in the $\mathrm{SpO}_{2}$ values (injured hand $83-86 \%$ as compared to normal hand $94-96 \%$ ). However $\mathrm{SpO}_{2}$ values were never below 75 
per cent which indicates presence of arterial pulsations. There was no obvious neurological deficit, so decision to manage conservatively was taken. We utilised finger probe for continuous $\mathrm{SpO}_{2}$ assessment during next 24 hours. $\mathrm{SpO}_{2}$ values showed gradual improvement over next 24 hours and reached normal values of 94 per cent. Surgical interference in a major arterial injury at elbow is not far from risk. Borderline cases of contusion or temporary spasm need no exploration but close observation. In such cases continuous $\mathrm{SpO}_{2}$ measurements can give better idea about peripheral circulatory status than clinical assessment [3]. A deterioration in the $\mathrm{SpO}_{2}$ values over a time gives correct idea about progress and extent of damage and appropriate decision can be taken. Gradual improvement in $\mathrm{SpO}_{2}$ values in our case indicated temporary spasm or contusion, thus unnecessary exploration was avoided. We feel that in the present circumstances where doppler technique is not routinely available in our hospitals, therefore noninvasive monitoring of $\mathrm{SpO}_{2}$ for atleast first 24 hours can be a better and safe method of assessing peripheral circulation, specially in borderline cases and children as oximetry has not only dignostic but prognostic value [4].

\section{Lt Col AK AGASHE}

Classified Specialist (Anaesthesia)

Command Hospital (Eastern Command)

Calcutta

\section{REFERENCES}

1. Kelleher JH. Pulse oximetry. Journal of Clinical Monitoring 1989; 5: 37-62.

2. Rosenberg B, Rosenberg M, Birkhan J. Allen's test performed by the pulse oximeter. Anesthesia 1988; 43:515-6

3. Tremper KK, Barker SJ. Pulse oxımetry. Anesthesiology 1989; 70: 98-108.

4. Joyce WP, Walsh K, Gough DB, Gorey TF, Fitzpatrick JM. Pulse oximetry: A new noninvasive assessment of peripheral arterial occlusive disease. Br J of Surg 1990; 77: I115-7.

\section{INTERPLEURAL ANALGESIA FOR BREAST SURGERY}

\section{Dear Editor,}

$\mathbf{I}_{\mathrm{in}}^{\mathrm{n}}$ nterpleural analgesia (IPA) for surgeries over areas innervated by intercostal nerves, is a relatively new technique described less than two decades ago [1]. The technique is simple, avoids multiple intercostal nerve blockade, allows catheter placement and therefore continuous and high quality analgesia. Adverse effects including pneumo-thorax are extremely uncommon. A brief account of a case is presented where IPA was used to provide analgesia following surgery on the breast.

A 49-year-old lady weighing $60 \mathrm{~kg}$ was posted for excision of a lump measuring $5 \times 3 \mathrm{~cm}$ in breast on the right side. She was given anaesthesia in accordance with the standard policy. During surgery, the lump appeared to be precancerous hence a wide excision was carried out by extending the incision over upper quadrant upto anterior axillary line. After completion of the surgery the patient was turned into lateral decubitus position with operated side up and a mild head down tilt. A $16 \mathrm{G}$ catheter was passed in 7 th intercostal space on the right side about $8 \mathrm{~cm}$ from central spinc. The catheter was placed in the pleural cavity and secured. $20 \mathrm{~mL}$ of 0.5 per cent bupivacaine was injected after taking due precaution. After maintaining the position for 5 minutes, the patient was straightened and residual myoneural blockade was reversed. The patient remained absolutely comfortable for 24 hours and did not demand analgesia. There was no untoward event. After 24 hours, $10 \mathrm{~mL}$ of 0.5 per cent bupivacaine was repeated in the same position as described above and thereafter the catheter was removed. She did not require any analgesic medication subsequently and had an uneventful recovery.

IPA is now an acceptable technique of pain relief in surgeries on gall bladder and kidney, fracture of ribs and thoracotomies. However, it has been found to be equally effective in surgery on the breast. Schlesinger et al used IPA satisfactorily as the sole anaesthetic technique for mammography during needle localization and for subsequent breast biopsy [2]. Reistad and McIlvaine also found this technique causing complete skin anaesthesia over T-1 to T-9 dermatomes to allow breast surgery [3]. The technique does produce adequate analgesia as noted in outgoing report however it needs to be studied further. A study of interpleural analgesia in upper abdominal surgeries as compared to intramuscular pethidine is already underway at this hospital and preliminary results are expected to be published soon.

\section{Maj DK SREEVASTAVA}

Graded Specialist (Anaesthesiology)

Military Hospital Jhansi

\section{REFERENCES}

1. Murphy DF. Intcrpleural Analgesia. Br J Anaesth 1993; 71: 426-34.

2. Schlesinger TM, Laurito CE, Baughman VL, Carranga CJ. Interpleural bupivacaine for mammography during needle localisation and breast biopsy. Anesth Analg 1989; 68: 394-5.

3. Reistad E. Mcllvaine WB. Interpleural anaesthesia for extracorporeal shock wave lithotripsy. Anesth Analg 1989; 69: 551-2.

\section{MASS DECOCKROACHING : AN EFFECTIVE CONTROL MEASURE IN MULTI STOREYED BUILDINGS}

\section{Dear Editor,}

C Yockroaches are annoying domestic pests imparting a nauseating "Cockroach" odour to the food articles and utensils they come in contact with and the places they infest. They may spread diseases like cholera, typhoid and dysentery by polluting food with filth carried on their legs and bodies [1].

Adult female cockroach lays eggs inside egg case which hatch out in 2-4 weeks depending on species and environmental conditions. The nymphal stages do not differ greatly from those of adults in body form and habits and develop into adult cockroaches in about 2-3 months. Laying of eggs occur after copulation and development of ootheca; thus completing the life cycle. Conventional control measures are aimed at nymphal and adult stages only [2,3].

The problem of cockroach control in the Armed Forces has not been given importance due to pre-occupation of available health manpower on mosquito control measures. Moreover, cockroach nuisance is usually not an acute problem in personnel lines. The problems in married accomodation are usually tackled individually by the residents based on their perceptions. However multi-storeyed buildings with varying degrees of sanitation in individual flats and multitude of potential hiding places besides a central garbage chute provide immense potential for hiding and breeding of cockroaches. 